\title{
Some Ternary Phenylmethoxybis(tetrazolium) Complexes of Vanadium(IV,V) and Their Constants of Association
}

\author{
Kiril Blazhev Gavazov, ${ }^{\text {a,* }}$ Petya Vasileva Racheva, ${ }^{\text {b }}$ Vanya Dimitrova Lekova, ${ }^{\mathrm{a}}$ \\ Atanas Nikolov Dimitrov, ${ }^{a}$ Murat Türkyilmaz, ${ }^{\mathrm{c}}$ and Fatma Genç ${ }^{\mathrm{c}}$ \\ apepartment of General and Inorganic Chemistry, University of Plovdiv "Paisii Hilendarski", \\ 24 Tsar Assen Str., 4000 Plovdiv, Bulgaria \\ ${ }^{\mathrm{b}}$ Department of Chemistry and Biochemistry, Medical University Plovdiv, 15 A Vassil Aprilov Blvd., 4002 Plovdiv, Bulgaria \\ ${ }^{\mathrm{c}}$ Faculty of Science, Chemistry Department, University of Trakya, 22030 Edirne, Turkey
}

RECEIVED FEBRUARY 22, 2011; REVISED JULY 21, 2011; ACCEPTED OCTOBER 17, 2011

\begin{abstract}
Several liquid-liquid extraction systems containing vanadium $\{$ vanadium(IV) or vanadium(V)\}, azoderivative of resorcinol \{ADR: 4-(2-pyridylazo)-resorcinol (PAR) or 4-(2-thiazolylazo)-resorcinol (TAR)\} and (phenylmethoxibis)tetrazolium salts \{MBT: 3,3'-(3,3'-dimetoxy-4,4'-biphenylene)-bis(2,5diphenyl-2H-tetrazolium) chloride (Blue Tetrazolium, BT) or 3,3'-(3,3'-dimetoxy-4,4'-biphenylene)bis[2,5-di(4-nitrophenyl)-2H-tetrazolium] chloride (Tetranitroblue Tetrazolium, TNBT)\} were studied. The optimum operating conditions and compositions of the extracted species were found. The constants of association $(\beta)$ between $\mathrm{MBT}^{2+}$ and the anionic $\mathrm{V}-\mathrm{ADR}$ chelates $\left(\mathrm{Chel}^{n-}\right)$ were calculated. Previously reported negative linear relationship between $\log \beta$ and the number of nitro groups included in tetrazolium cation $\left(N_{\text {nitro }}\right)$ was discussed taking into account the obtained results and literature data for V-ADR-MBT complexes of the same class, in which MBT is BT or 3,3'-(3,3'-dimetoxy-4,4'-biphenylene)bis[2-(4nitrophenyl)-5-phenyl-2H-tetrazolium] chloride (Nitroblue Tetrazolium, NBT). (doi: 10.5562/cca1885)
\end{abstract}

Keywords: vanadium, ditetrazolium salts, azocompounds, association constant, nitro group, solvent extraction

\section{INTRODUCTION}

Tetrazolium salts (TS) are compounds possessing a five-membered ring of one carbon and four nitrogen atoms; one of these atoms bears a positive carge. The most important are trisubstituted mono- and di-TS which contain a substituent at the carbon atom (position 5 in tetrazolium ring). ${ }^{1-11}$ TS attracted our attention thanks to the ability of their cations to form ionassociation complexes (IAC), which allow sensitive and selective liquid-liquid extraction-spectrophotometric or potentiometric determination of many elements or species involved in the anionic part of the IAC. ${ }^{9-17}$ The extraction ability and analytical applicability of these complexes depend on their stability. ${ }^{9-11}$ That is why the estimation of constants, which characterize the process of association (Equation 1) between the tetrazolium cation $\mathrm{T}^{m^{+}}$and various anionic chelates $[\mathrm{Chel}]^{n-}$ is worth.

$$
\mathrm{T}^{m+}+[\mathrm{Chel}]^{n-} \stackrel{\beta}{\longleftrightarrow} \mathrm{T}_{n}[\text { Chel }]_{m}
$$

Continuous investigations on IACs of nine different commercially available tetrazolium salts revealed that at least two factors influent noticeable on the values of $\beta$ : molecular mass $\left(M_{\mathrm{T}^{m+}}\right)$ and the presence of nitrophenyl substituent(s) in the tetrazolium ring. ${ }^{10,11,18-}$ ${ }^{20}$ Alexandrov et al. ${ }^{11,18}$ disclosed the first factor: the higher the molecular mass, the higher the association constant. However, some further investigations showed that this statement is not valid for IACs, which include $\mathrm{NO}_{2}$ group(s) containing $\mathrm{T}^{m+} \cdot{ }^{10,19,20}$ In fact, the values of $\beta$ of such IACs are considerably lower than the expected ones according to literature. ${ }^{11,18}$ Next step of investigation on the problem was to compare the values of $\beta$ for IACs with $\mathrm{T}^{m+}$, which differs only by the number of $\mathrm{NO}_{2}$ groups $\left(N_{\text {nitro }}\right){ }^{21}$ For this purpose, the association constants of IACs between some phenylmethoxybis(tetrazolium) cations $\left(\mathrm{MBT}^{2+}\right)$, in which $N_{\text {nitro }}=0,2$, and 4 (Table 1), and the vanadi$\mathrm{um}(\mathrm{V})$ - 4-(2-pyridyl-azo)-resorcinol anionic chelate ${ }^{10,21,22}\left[\mathrm{VO}_{2}(\mathrm{PAR})_{2}\right]^{3-}$ were determined. The obtained results suggested that a linear relationship exists between $\log \beta$ and $N_{\text {nitro }}$ : the higher $N_{\text {nitro, }}$, the lower $\log \beta$

\footnotetext{
* Author to whom correspondence should be addressed. (E-mail: kgavazov@abv.bg)
} 
Table 1. Phenylmethoxybis(tetrazolium) chlorides (MBT) used or discussed in the present study

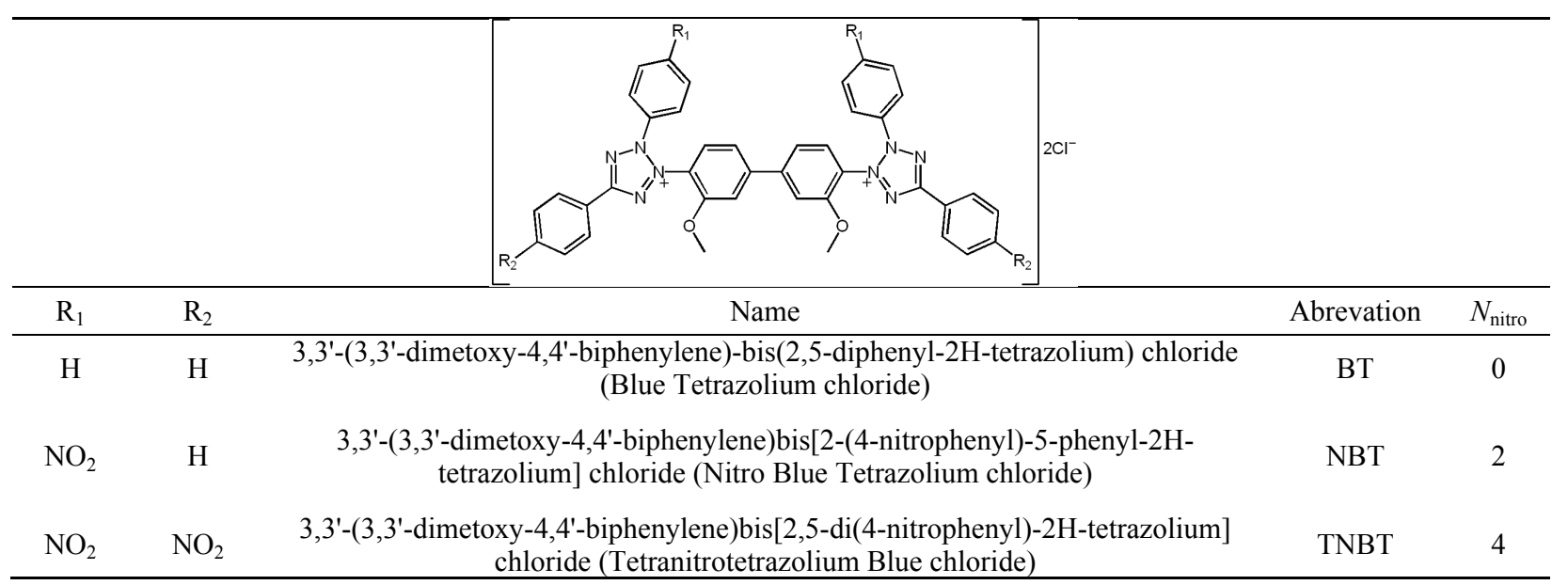

(Figure 1, straight line 1). ${ }^{21}$ Having in mind that such general conclusion may be rashly we decided to study the formation of several new IACs, which contain $\mathrm{MBT}^{2+}$, azoderivative of resorcinol $\{\mathrm{ADR}$ : PAR or 4(2-thiazolylazo)-resorcinol (TAR) $\}$ and vanadium $\{$ vanadium(IV) or vanadium(V)\}. Taking advantage of some recent investigations on the $\mathrm{V}(\mathrm{IV})$ complexes with NBT-PAR, ${ }^{23}$ BT-PAR, ${ }^{23}$ and NBT-TAR, ${ }^{24}$ and on the $\mathrm{V}(\mathrm{V})$ complexes with $\mathrm{BT}-\mathrm{TAR}^{20}$ and NBT-TAR ${ }^{20}$ we selected the following systems for the present study:

a) V(V)-TAR-TNBT-water-chloroform;

b) V(IV)-PAR-TNBT-water-chloroform;

c) V(IV)-TAR-BT-water-chloroform;

d) V(IV)-TAR-TNBT-water-chloroform.

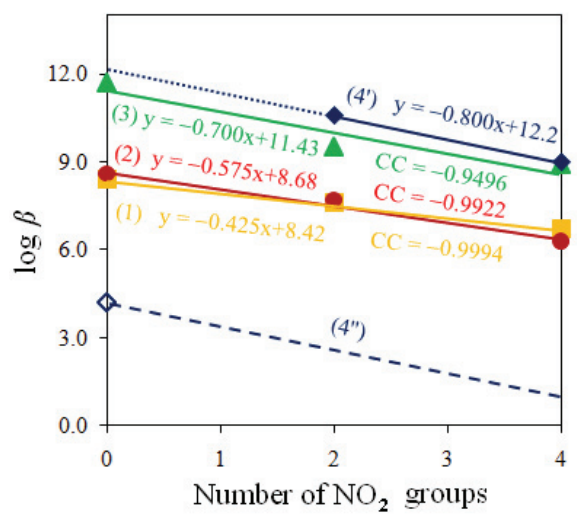

Figure 1. Logarithm of association constants of $\mathrm{MBT}^{2+}$ $[\mathrm{Chel}]^{m-}$ complexes $(\log \beta)$ vs. number of $\mathrm{NO}_{2}$ groups in $\mathrm{MBT}^{2+}$ plots. (1) $\mathrm{MBT}^{2+}-\left[\mathrm{VO}_{2}(\mathrm{PAR})_{2}\right]^{3-}$ systems; ${ }^{21}$ (2) $\mathrm{MBT}^{2+}-\left[\mathrm{VO}_{2}(\mathrm{TAR})_{2}\right]^{3-} \quad$ systems; (3) $\mathrm{MBT}^{2+}-\left[\mathrm{VO}(\mathrm{OH})_{2-}-\right.$ $\left.(\mathrm{PAR})_{2}\right]^{4-}$ systems; (4) $\mathrm{BT}^{2+}-\left[\mathrm{VO}(\mathrm{OH})_{2}(\mathrm{TAR})\right]^{2-}, \mathrm{NBT}^{2+}-$ $\left[\mathrm{VO}(\mathrm{OH})_{2}(\mathrm{TAR})_{2}\right]^{4-}$, and $\mathrm{TNBT}^{2+}-\left[\mathrm{VO}(\mathrm{OH})_{2}(\mathrm{TAR})_{2}\right]^{4-}$ systems. Stright line 4 ' is determined by the experimental points for systems involving $\mathrm{NBT}^{2+}$ or $\mathrm{TNBT}^{2+}$. Stright line 4" is determined by the point for the system involving $\mathrm{BT}^{2+}$.

\section{EXPERIMENTAL}

\section{Reagents and Apparatus}

Ammonium vanadate from VEB Laborchemie Apolda, purissimum, as a $2 \times 10^{-4} \mathrm{~mol} \mathrm{\textrm {dm } ^ { - 3 }}$ aqueous solution. $\mathrm{VOSO}_{4} \cdot 5 \mathrm{H}_{2} \mathrm{O}$ from Fluka AG, purum, as a $5 \times 10^{-2}$ mol $\mathrm{dm}^{-3}$ stock aqueous solution. The concentration was checked by titration with a standard solution of potassium permanganate. ${ }^{25}$ Working $2 \times 10^{-4} \mathrm{~mol} \mathrm{dm}^{-3}$ aqueous solutions acidified with sulphuric acid to $\mathrm{pH}=$ 2 to 3 were freshly prepared each day. Azoderivatives of resorcinol (ADR): PAR from Fluka, and TAR from Aldrich Chem. Co, as $2 \times 10^{-3} \mathrm{~mol} \mathrm{dm}^{-3}$ aqueous solutions. Phenylmethoxybis(tetrazolium) chlorides (MBT) from Sigma, as $2 \times 10^{-3} \mathrm{~mol} \mathrm{dm}^{-3}$ aqueous solutions. Redistilled chloroform was used. The acidity of aqueous medium was set by the addition of buffer solution, prepared by mixing of $0.1 \mathrm{~mol} \mathrm{dm}{ }^{-3}$ aqueous solutions of $\mathrm{CH}_{3} \mathrm{COOH}$ and $\mathrm{CH}_{3} \mathrm{COONa}$. The resulting $\mathrm{pH}$ was checked by HI $83140 \mathrm{pH}$ meter (Italy). A Camspec M508 spectrophotometer (United Kingdom), equipped with $10 \mathrm{~mm}$ path-length cells, was employed for reading the absorbance.

\section{Procedure for Establishing the Optimum Extraction- Spectrophotometric Conditions}

Aliquots of vanadium solution (V(IV) or V(V), 0.5-2.0 $\mathrm{cm}^{3}$ ), buffer solution $\left(3 \mathrm{~cm}^{3}\right)$, ADR solution (up to 1.5 $\mathrm{cm}^{3}$ ) and MBT solution (up to $1.5 \mathrm{~cm}^{3}$ ) were introduced into $125-\mathrm{cm}^{3}$ separatory funnels. The resulting solutions were diluted with distilled water to a total volume of 10 $\mathrm{cm}^{3}$. Then $10 \mathrm{~cm}^{3}$ of chloroform was added and the funnels were shaken for 0.5-2 min. After phase separation, the organic layer was homogenized. A portion of the extract was transferred through a filter paper into a cell and the absorbance was read against a simultaneously prepared blank. 
Table 2. Optimum conditions ${ }^{(a)}$ and characteristics of the extracted species in the vanadium azoderivative of resorcinol(phenylmethoxybis)-tetrazolium systems

\begin{tabular}{|c|c|c|c|c|c|c|c|c|}
\hline $\begin{array}{l}\text { Extraction } \\
\text { System }\end{array}$ & $\begin{array}{l}\text { Suggested Formulae of } \\
\text { the Extracted Species }\end{array}$ & $\lambda_{\max } / \mathrm{nm}$ & $\mathrm{pH}_{\mathrm{opt}}$ & $t_{\mathrm{ex}} / \min$ & $\varepsilon / 10^{4} \mathrm{dm}^{3} \mathrm{~mol}^{-1} \mathrm{~cm}^{-1}$ & $\frac{n\left(\mathrm{MBT}^{2+}\right)}{n\left(\mathrm{Chel}^{n-}\right)}$ & $\log \beta$ & Ref. \\
\hline \multirow{3}{*}{$\begin{array}{l}\mathrm{V}(\mathrm{V})- \\
\text { PAR- } \\
\text { MBT- } \\
\mathrm{H}_{2} \mathrm{O}- \\
\mathrm{CHCl}_{3}\end{array}$} & $(\mathrm{BT})_{3}\left[\mathrm{VO}_{2}(\mathrm{PAR})_{2}\right]_{2}$ & 560 & $5.15 \pm 0.45$ & 2 & 4.0 & $3: 2$ & $8.4 \pm 0.4$ & 21 \\
\hline & $(\mathrm{NBT})_{3}\left[\mathrm{VO}_{2}(\mathrm{PAR})_{2}\right]_{2}$ & 560 & $5.25 \pm 0.55$ & 2 & 3.2 & $3: 2$ & $7.6 \pm 0.3$ & 21 \\
\hline & $(\mathrm{TNBT})_{3}\left[\mathrm{VO}_{2}(\mathrm{PAR})_{2}\right]_{2}$ & 560 & $5.85 \pm 0.25$ & 2 & 1.9 & $3: 2$ & $6.7 \pm 0.3$ & 21 \\
\hline \multirow{3}{*}{$\begin{array}{l}\mathrm{V}(\mathrm{IV})- \\
\text { PAR- } \\
\text { MBT- } \\
\mathrm{H}_{2} \mathrm{O}- \\
\mathrm{CHCl}_{3}\end{array}$} & $(\mathrm{BT})_{2}\left[\mathrm{VO}(\mathrm{OH})_{2}(\mathrm{PAR})_{2}\right]$ & 558 & $4.85 \pm 0.05$ & 1.5 & 3.3 & $2: 1$ & $11.7 \pm 1.3$ & 23 \\
\hline & $(\mathrm{NBT})_{2}\left[\mathrm{VO}(\mathrm{OH})_{2}(\mathrm{PAR})_{2}\right]$ & 559 & $4.2 \pm 0.5$ & 1.5 & 3.6 & $2: 1$ & $9.5 \pm 0.9$ & 23 \\
\hline & $(\mathrm{TNBT})_{2}\left[\mathrm{VO}(\mathrm{OH})_{2}(\mathrm{PAR})_{2}\right]$ & 560 & $4.4 \pm 0.4$ & 1.5 & 2.3 & $2: 1$ & $8.9 \pm 0.7$ & This work \\
\hline \multirow{3}{*}{$\begin{array}{l}\mathrm{V}(\mathrm{V})- \\
\text { TAR- } \\
\text { MBT- } \\
\mathrm{H}_{2} \mathrm{O}- \\
\mathrm{CHCl}_{3}\end{array}$} & $(\mathrm{BT})_{3}\left[\mathrm{VO}_{2}(\mathrm{TAR})_{2}\right]_{2}$ & 550 & $5.2 \pm 0.5$ & 2 & 2.5 & $3: 2$ & $8.6 \pm 0.5$ & 20 \\
\hline & $(\mathrm{NBT})_{3}\left[\mathrm{VO}_{2}(\mathrm{TAR})_{2}\right]_{2}$ & 550 & $5.4 \pm 0.3$ & 2 & 2.4 & $3: 2$ & $7.7 \pm 0.4$ & 20 \\
\hline & $(\mathrm{TNBT})_{3}\left[\mathrm{VO}_{2}(\mathrm{TAR})_{2}\right]_{2}$ & 550 & $5.60 \pm 0.05$ & 2 & 1.3 & $3: 2$ & $6.3 \pm 0.6$ & This work \\
\hline \multirow{3}{*}{$\begin{array}{l}\text { V(IV)- } \\
\text { TAR- } \\
\text { MBT- } \\
\mathrm{H}_{2} \mathrm{O}- \\
\mathrm{CHCl}_{3} \\
\end{array}$} & $(\mathrm{BT})\left[\mathrm{VO}(\mathrm{OH})_{2}(\mathrm{TAR})\right]$ & 555 & $5.2 \pm 0.3$ & 2 & 2.4 & $1: 1$ & $4.2 \pm 0.7$ & This work \\
\hline & $(\mathrm{NBT})_{2}\left[\mathrm{VO}(\mathrm{OH})_{2}(\mathrm{TAR})_{2}\right]$ & 550 & $4.95 \pm 0.35$ & 2 & 2.8 & $2: 1$ & $10.6 \pm 0.8$ & 24 \\
\hline & $(\mathrm{TNBT})_{2}\left[\mathrm{VO}(\mathrm{OH})_{2}(\mathrm{TAR})_{2}\right]$ & 550 & $4.75 \pm 0.10$ & 2 & 1.9 & $2: 1$ & $9.0 \pm 0.7$ & This work \\
\hline
\end{tabular}

(a) Optimum ADR and MBT concentration in all systems is $2 \times 10^{-4} \mathrm{~mol} \mathrm{dm}^{-3}$.

\section{Procedure for the Determination of ADR/V and MBT/V Molar Ratios}

The ADR/V and MBT/V molar ratios were determined by the procedure mentioned above according to the equilibrium shift method ${ }^{26}$ and the method of Asmus. ${ }^{26}$ The experiments were performed at the optimum $\mathrm{pH}$ and optimum MBT concentration $\left(2 \times 10^{-4} \mathrm{~mol} \mathrm{dm}^{-3}\right.$; at determining the ADR/V molar ratios) or optimum ADR concentration $\left(2 \times 10^{-4} \mathrm{~mol} \mathrm{dm}{ }^{-3}\right.$; at determining the $\mathrm{MBT} / \mathrm{V}$ molar ratios). The concentration of $\mathrm{V}(\mathrm{IV})$ or $\mathrm{V}(\mathrm{V})$ was 10 times smaller $\left(2 \times 10^{-5} \mathrm{~mol} \mathrm{dm}^{-3}\right)$.

\section{Procedure for Determination of the Constants of Association}

The constants of association $\beta$ were determined according to the method of Komar-Tolmachev. ${ }^{26}$ The procedure mentioned above (procedure for establishing the optimum extraction-spectrophotometric conditions) was used with the following peculiarities: 1) The samples were run at the optimum $\mathrm{pH}$, optimum ADR concentration and different vanadium concentrations (from $1 \times$ $10^{-5}$ to $4 \times 10^{-5} \mathrm{~mol} \mathrm{dm}^{-3}$ ); 2) The MBT/V concentration ratio was maintained to be $n / m$ (see Equation 1).

\section{RESULTS AND DISCUSSION}

\section{Vanadium(V)-TAR-MBT-Water-Chloroform Systems}

It is known that $\mathrm{V}(\mathrm{V})$ forms ternary complexes with TAR and $\mathrm{BT}^{2+}$ or $\mathrm{NBT}^{2+},{ }^{20}$ which could be represented with the general formula $(\mathrm{MBT})_{3}\left[\mathrm{VO}_{2}(\mathrm{TAR})_{2}\right]_{2}$. The absorption maximum of both the complexes is at $\lambda=$ $550 \mathrm{~nm}$, however there are some differences in the molar absorptivity and $\mathrm{pH}$ interval of maximum extraction (Table 2). The present investigations on the vanadium(V)-TAR-TNBT-water-chloroform system showed that $\lambda_{\max }$ of the extracted ternary complex is also at 550 nm (Figure 2, curve 1). The TAR/V(V) and TNBT/V(V) molar ratios in it were determined to be 2 and 1.5 , respectively. These experimental results give us ground to represent the complex with the general formula mentioned above. Taking into account the state of $\mathrm{V}(\mathrm{V})^{27}$ and $\mathrm{TAR}^{28}$ in aqueous solutions at the optimum $\mathrm{pH}$ we suggest the following scheme of complex formation:

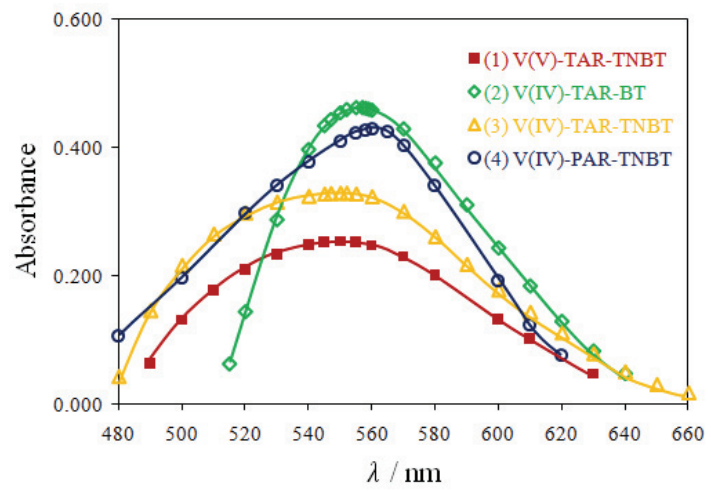

Figure 2. Absorption spectra in chloroform. $c(\mathrm{~V}(\mathrm{~V}))=$ $c(\mathrm{~V}(\mathrm{IV}))=2.0 \times 10^{-5} \mathrm{~mol} \mathrm{dm}^{-3}, c(\mathrm{ADR})=c(\mathrm{MBT})=2.0 \times$ $10^{-4} \mathrm{~mol} \mathrm{dm}{ }^{-3}, \mathrm{pH}=5.5$ (curve 1), $\mathrm{pH}=4.9$ (curves 2 and 3 ) and $\mathrm{pH}=4.8$ (curve 4 ). 


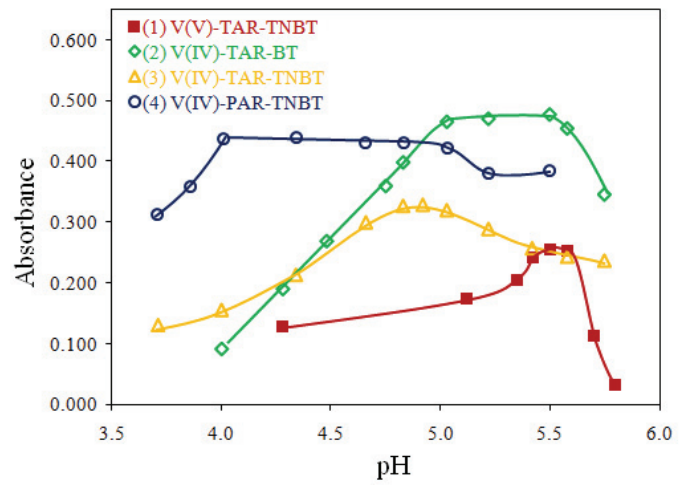

Figure 3. Absorbance of $\mathrm{V}(\mathrm{IV}, \mathrm{V})$ - ADR - MBT complexes in chloroform $v s . \mathrm{pH}$ of the aqueous phase plots. $c(\mathrm{~V}(\mathrm{~V}))=$ $c(\mathrm{~V}(\mathrm{IV}))=2.0 \times 10^{-5} \mathrm{~mol} \mathrm{dm}^{-3}, c(\mathrm{ADR})=c(\mathrm{MBT})=2.0 \times 10^{-4}$ $\mathrm{mol} \mathrm{dm}{ }^{-3}$.

$$
\begin{array}{r}
\mathrm{H}_{2} \mathrm{VO}_{4}^{-}+2 \mathrm{H}_{2}(\mathrm{TAR}) \longleftrightarrow \\
{\left[\mathrm{VO}_{2}(\mathrm{TAR})_{2}\right]^{3-}+2 \mathrm{H}_{2} \mathrm{O}+2 \mathrm{H}^{+}} \\
2\left[\mathrm{VO}_{2}(\mathrm{TAR})_{2}\right]^{3-}+3 \mathrm{TNBT}^{2+} \longleftrightarrow \\
(\mathrm{TNBT})_{3}\left[\mathrm{VO}_{2}(\mathrm{TAR})_{2}\right]_{2}
\end{array}
$$

\section{Vanadium(IV)-PAR-MBT-Water-Chloroform Systems}

The complex formation in the systems V(IV)-PAR-NBTwater-chloroform and V(IV)-PAR-BT-water-chloroform has been studied in Reference 23. A ternary complex with $\lambda_{\max }=559 \mathrm{~nm}$ and a presumable formula (NBT) $)_{2}$ [VO$\left.(\mathrm{OH})_{2}(\mathrm{PAR})_{2}\right]$ has been found in the former system. At similar extraction conditions, the system with BT has been found more complicated. At least two different complex species have been detected into the organic phase. The dominant complex at the optimum extractionspectrophotometric conditions (Table 2) most probably is similar to those with NBT: $(\mathrm{BT})_{2}\left[\mathrm{VO}(\mathrm{OH})_{2}(\mathrm{PAR})_{2}\right]{ }^{23}$ It should be mentioned that at $\mathrm{pH} \geq 5.1 \mathrm{~V}(\mathrm{IV})$ in both the systems, V(IV)-PAR-NBT and V(IV)-PAR-BT, is partially oxidised by the atmospheric oxigen to $V(V)$. Such an oxidation has been observed in other V(IV)-PAR containing systems; ${ }^{29-31}$ it could be avoided if special precautions are taken: inert atmosphere,$^{30}$ low temperature and flushing the solutions with nitrogen. ${ }^{32}$

Our present investigations on the vanadium(IV)PAR-TNBT-water-chloroform system showed that the optimum $\mathrm{pH}$ range for extraction of $\mathrm{V}(\mathrm{IV})$ is $\mathrm{pH}=4.0$ to 4.9 (Figure 3, curve 4), $\lambda_{\max }$ appears at $560 \mathrm{~nm}$ (Figure 2, curve 4), and both the molar ratios PAR:V(IV) and TNBT:V(IV) are 2:1. Having in mind the state of V(IV) $)^{33}$ and $\mathrm{PAR}^{28,34}$ at the optimum acidity, and the literature ${ }^{23}$ we suggest the following scheme of complex formation:

$$
\begin{aligned}
& \mathrm{VO}(\mathrm{OH})_{2}+2 \mathrm{H}(\mathrm{PAR})^{-} \longleftrightarrow \\
& {\left[\mathrm{VO}(\mathrm{OH})_{2}(\mathrm{PAR})_{2}\right]^{4-}+2 \mathrm{H}^{+} }
\end{aligned}
$$

$$
\begin{aligned}
& {\left[\mathrm{VO}(\mathrm{OH})_{2}(\mathrm{PAR})_{2}\right]^{4-}+} 2 \mathrm{TNBT}^{2+} \longleftrightarrow \\
&(\mathrm{TNBT})_{2}\left[\mathrm{VO}(\mathrm{OH})_{2}(\mathrm{PAR})_{2}\right]
\end{aligned}
$$

\section{Vanadium(IV)-TAR-MBT-Water-Chloroform Systems}

The complexes formed in the V(IV)-TAR aqueous system are more unstable than these in the systems $\mathrm{V}(\mathrm{V})$ $\mathrm{TAR}^{35}$ and V(IV)-PAR. ${ }^{30}$ They are considerably affected by hydrolysis at $\mathrm{pH}=4.5$ to $5.5,{ }^{24,35}$ and have no analytical application. ${ }^{36,37}$ On the other hand the association constants of $\mathrm{T}^{m+}-(\mathrm{V}-\mathrm{TAR})^{n-}$ are higher than those of the corresponding $\mathrm{T}^{m+}-(\mathrm{V}-\mathrm{PAR})^{n-} \cdot{ }^{10,24}$ Having in mind the tendency to hydrolysis and relative instability of the species V(IV)-TAR, it is not surprising that ternary complexes with different compositions have been obtained, varying $\mathrm{T}^{m+}, \mathrm{pH}$ and reagent concentrations. ${ }^{24}$

Our investigations on the V(IV)-TAR-TNBTwater-chloroform system showed that the ternary complex formation could be represented as in the similar system with NBT: ${ }^{24}$

$$
\begin{gathered}
\mathrm{VO}(\mathrm{OH})_{2}+2 \mathrm{H}_{2}(\mathrm{TAR}) \longleftrightarrow \\
{\left[\mathrm{VO}(\mathrm{OH})_{2}(\mathrm{TAR})_{2}\right]^{4-}+4 \mathrm{H}^{+}} \\
{\left[\mathrm{VO}(\mathrm{OH})_{2}(\mathrm{PAR})_{2}\right]^{4-}+2 \mathrm{TNBT}^{2+} \longleftrightarrow} \\
(\mathrm{TNBT})_{2}\left[\mathrm{VO}(\mathrm{OH})_{2}(\mathrm{PAR})_{2}\right]
\end{gathered}
$$

Evidences for the formation of such a complex are the molar ratios TAR/V(IV) and TNBT/V(IV) equal to 2, and the identical character of the spectral curves of V(IV)TAR-TNBT and V(IV)-TAR-NBT ${ }^{24}$ in chloroform.

The conclusions drawn at studing the similar system with BT, however, were different. TAR/V(IV) and $\mathrm{BT} / \mathrm{V}(\mathrm{IV})$ ratio in the ternary complex were $1: 1$ and the absorbance maximum appeared at different wavelength: $555 \mathrm{~nm}$ (Figure 2, curve 2). Taking into account the obtained results, we suggest the following scheme of complex formation at $\mathrm{pH} \approx 5$ :

$$
\begin{gathered}
\mathrm{VO}(\mathrm{OH})_{2}+\mathrm{H}_{2}(\mathrm{TAR}) \longleftrightarrow \\
{\left[\mathrm{VO}(\mathrm{OH})_{2}(\mathrm{TAR})\right]^{2-}+2 \mathrm{H}^{+}} \\
{\left[\mathrm{VO}(\mathrm{OH})_{2}(\mathrm{TAR})\right]^{2-}+\mathrm{BT}^{2+} \longleftrightarrow} \\
(\mathrm{BT})\left[\mathrm{VO}(\mathrm{OH})_{2}(\mathrm{TAR})\right]
\end{gathered}
$$

In spite of the fact that V(IV) in TAR- $\mathrm{T}^{m+}$ systems has been found less susceptible to oxidation than in the corresponding systems with participation of $\mathrm{PAR}^{24}$ the formation of minor $\mathrm{V}(\mathrm{V})$-TAR anionic species cannot be excluded at $\mathrm{pH} \approx 5.5$.

\section{Relationship Between $\log \beta$ and Number of $\mathrm{NO}_{2}$ Groups}

The constant of association characterizing the equations $2^{\prime}, 3^{\prime}, 4^{\prime}$, and $5^{\prime}$ were determined at $3: 2,2: 1,2: 1$, and $1: 1$ 
MBT/vanadium concentration ratios, respectively. Calculated values are shown in Table 2 and the relationships between $\log \beta$ and $N_{\text {nitro }}$ for the systems described above are represented in Figure 1, straight lines 2-4.

Straight lines 2 and 3 show the dependences for the associates between $\mathrm{MBT}^{2+}$ and $\left[\mathrm{VO}_{2}(\mathrm{TAR})_{2}\right]^{3-}$ or $[\mathrm{VO}-$ $\left.(\mathrm{OH})_{2}(\mathrm{PAR})_{2}\right]^{4-}$, respectively. The calculated correlation coefficients (CC) are close to -1 , what supports the conclusion $^{21}$ that negative linear relationship exists between $\log \beta$ and $N_{\text {nitro }}$ : the higher $N_{\text {nitro, }}$, the lower $\log \beta$.

The trend of decreasing $\log \beta$ with increasing $N_{\text {nitro }}$ could be seen in Figure 1, straight-line 4' for the complexes $(\mathrm{NBT})_{2}\left[\mathrm{VO}(\mathrm{OH})_{2}(\mathrm{TAR})_{2}\right]$ and $(\mathrm{TNBT})_{2}[\mathrm{VO}-$ $(\mathrm{OH})_{2}(\mathrm{TAR})_{2}$ ] as well. The $\log \beta$ values of these two associates determine a straight-line with a slope of -0.800 , which is slightly higher than those for $(\mathrm{MBT})_{2}-$ $\left[\mathrm{VO}(\mathrm{OH})_{2}(\mathrm{PAR})_{2}\right]$ series (Figure 1, straight line 3$)$. The complex with $\mathrm{BT}$, namely $(\mathrm{BT})\left[\mathrm{VO}(\mathrm{OH})_{2}\right.$-(TAR)], has a different composition. Its anionic part has a different charge (2-) and the $\log \beta$ value should not be compared with the corresponding values of $(\mathrm{NBT})_{2}$ [VO$\left.(\mathrm{OH})_{2}(\mathrm{TAR})_{2}\right]$ and $(\mathrm{TNBT})_{2}\left[\mathrm{VO}(\mathrm{OH})_{2}(\mathrm{TAR})_{2}\right]$.

\section{Some Calculations Based on the Linear Model $\log \beta=f\left(N_{\text {nitro }}\right)$}

$(\mathrm{BT})_{2}\left[\mathrm{VO}(\mathrm{OH})_{2}(\mathrm{TAR})_{2}\right]$ is a missing member of the $(\mathrm{MBT})_{2}\left[\mathrm{VO}(\mathrm{OH})_{2}(\mathrm{TAR})_{2}\right]$ series. Calculations based on the linear model $\log \beta=b N_{\text {nitro }}+a$ (Figure 1, straight line 4 ' with a slope of $b=-0.800$ ) show that $\log \beta$ value for this hypothetical complex should be close to 12.2 . The mentioned value is higher than these for the reported $^{10}$ real tetrazolium associates $\mathrm{T}_{n}[\mathrm{Chel}]_{m}$ with $n / m=2$. Such a value corresponds to a very short distance between the cationic and anionic parts of the ionassociate. ${ }^{38}$ Therefore, steric factors may act, preventing the formation of $\mathrm{BT}^{2+}$-complex with the abovementioned formula.

The complex with 1:1 $\mathrm{BT}^{2+}$-to-[VO $\left.(\mathrm{OH})_{2}(\mathrm{TAR})\right]^{2-}$ ratio is the only experimentally established member of the (MBT) $\left[\mathrm{VO}(\mathrm{OH})_{2}(\mathrm{TAR})\right]$ series. Calculations based on the straight-line equation $\log \beta=b N_{\text {nitro }}+a$ (dashed straight line 4" constructed arbitrary with the same slope of -0.800 ; Figure 1) show that the rest two members of this series should be very unstable with $\log$ $\beta_{(\mathrm{NBT})\left[\mathrm{VO}(\mathrm{OH})_{2}(\mathrm{TAR})\right]}=2.6$ and $\log \beta_{(\mathrm{TNBT})\left[\mathrm{VO}(\mathrm{OH})_{2}(\mathrm{TAR})\right]}=1.0$. The mentioned values are lower than these for the normally existing associates $\mathrm{T}_{n}[\mathrm{Chel}]_{m}$ with $m=n=1{ }^{10}$

Having in mind these calculations one can conclude that the slope $b$ of the stright $\operatorname{line} \log \beta=b N_{\text {nitro }}+$ $a$ is an important characteristic of the system $\mathrm{MBT}^{2+}-$ $[\mathrm{Chel}]^{n-}$. Probably $b$ may serve as an indicator for the stability of $[\mathrm{Chel}]^{\mathrm{n}-}$ and the posibility of existence of $\mathrm{BT}^{2+}, \mathrm{NBT}^{2+}$ and $\mathrm{TNBT}^{2+}$ complexes with the same composition. It should be mentioned that the stability of $[\mathrm{Chel}]^{n-}$ in ternary tetrazolim IACs with participation of
ADR is sometimes unknown due to the fact that $\mathrm{T}^{m+}$ (in particular $\mathrm{MBT}^{2+}$ ) could stabilize different anionic species (e.g. with 2:1 ADR/V ratio ${ }^{10,20-24,39}$ ) in comparison to these obtained in aqueous solutions $\mathrm{s}^{29,30,32,35}$ or by extraction with other heavy organic salts. ${ }^{34,40-42}$

\section{CONCLUSIONS}

Vanadium forms well extractable into chloroform ternary complexes with ADR and MBT. The extractionspectrophotometric properties and analytical applicability of these complexes depend on several factors, including stability of both: anionic chelate and ionassociate. Vanadium(V) forms stable anionic chelates with ADR. In presence of $\mathrm{MBT}^{2+}$ these chelates converts into ternary complexes with colour properties depending on the stability of associate. Because, the order of stability decreases with the increasing of $N_{\text {nitro }}$ the complexes of $\mathrm{BT}^{2+}$ are more appropriate for analytical applications that these of TNBT ${ }^{2+}$ and $\mathrm{NBT}^{2+}$.

Vanadium(IV) forms less stable ADR anionic chelates than vanadium(V), which are affected by hydrolysis. In presence of $\mathrm{MBT}^{2+}$ these chelates also convert into ternary complexes, however, the nature of $\mathrm{MBT}^{2+}$ is a key factor determining the stabilization of one anionic species or another. The chemical behavior of $\mathrm{TNBT}^{2+}$ is close to that of $\mathrm{NBT}^{2+}$, most probably due to the presence of $\mathrm{NO}_{2}$. At the same time, $\mathrm{BT}^{2+}$ is different in some extent; it could stabilize different anionic species in the ion-associate.

The present investigations confirm the conclusions given in Reference 21 for the existence of negative linear relationship between $\log \beta$ and $N_{\text {nitro }}$. At the same time, they contribute to a better understanding of some aspects concerning the chemistry of MBT and may serve as an improved tool for the prediction of some key characteristics of uninvestigated or partially investigated MBT complexes: stability, composition, color properties and analytical applicability.

Acknowledgements. This work was supported by the Research Fund of the University of Plovdiv "Paisii Hilendarski" (Grant No NI11-HF-007).

\section{REFERENCES}

1. M. V. Berridge, P. M. Herst, and A. S. Tan, Biotechnol. Annu. Rev. 11 (2005) 127-152.

2. X. Li, S. Deng, and H. Fu, Corros. Sci. 53 (2011) 302-309.

3. A. G. F. Elsaid, N. M. H. Rizk, and A. B. H. Matter, Asian J. Chem. 22 (2010) 1736-1744.

4. T. Tsukatani, H. Suenaga, M. Ishiyama, T. Ezoe, and M. K., Food Chem. 127 (2011) 711-715.

5. A. Kovacs, L. Wojnarovits, T. Palfi, G. Emi-Reynolds, and J. Fletcher, Radiat. Phys. Chem. 77 (2008) 1088-1092.

6. P. Gymez-Ochoa, A. Lara, G. Couto, J. M. Marcen, A. Peris, M. Gascyn, and J. A. Castillo, Vet. Parasitol. 172 (2010) 135-138. 
7. A. A. Basfar, K. A. Rabeh, A. A. Moussa, and R. I. Msalam, Radiat. Phys. Chem. 201180 (2011) 763-766.

8. A. B. Zhivich, G. I. Koldobskii, and V. A. Ostrovskii, Chem. Hetero. Comp. 26 (1990) 1319-1328.

9. A. Alexandrov, Tertazolium Salts for Solvent Extraction of Elements as Ion Association Complexes. Review, Universität des Saarlandes, Saarbrücken, 1984.

10. K. B. Gavazov, A. N. Dimitrov, and V. D. Lekova, Uspekhi Khim. 76 (2007) 187-198.

11. A. Alexandrov, Tetrazolium salts as reagents in analytical chemistry, Doctoral Thesis in Chemical Sciences, BAS, Sofia, Bulgaria, 1987.

12. K. B. Gavazov, Z. Simeonova, and A. Alexandrov, Talanta 52 (2000) 539-544.

13. M. M. Hassanien, K. S. Abou-El-Sherbini, and G. A. E. Mostafa, Talanta 59 (2003) 383-392.

14. M. N. Abbas and G. A. E. Mostafa, Anal. Chim. Acta 478 (2003) 329-335.

15. G. A. E. Mostafa, Talanta 71 (2007) 1449-1454.

16. M. Kamburova and D. Kostova, Chemija 19 (2008) 13-18.

17. L. Dospatliev, N. V. Georgieva, A. I. Pavlov, and Z. Yaneva, Trakia J. Sci. 8 (2010) 16-19.

18. A. Alexandrov, Z. Simeonova, and M. Kamburova, Bulg. Chem. Commun. 23 (1990) 542-544.

19. K. Gavazov, A. Dimitrov, V. Lekova, and E. Karaasenova, Nauch. Tr. Plovdiv Univ. Khim. 34 (2006) 19-27.

20. K. B. Gavazov, V. D. Lekova, A. N. Dimitrov, and G. I. Patronov, Cent. Eur. J. Chem. 5 (2007) 257-270.

21. K. B. Gavazov, M. Türkyilmaz, and Ö. Altun, Bulg. Chem. Commun. 40 (2008) 65-69.

22. K. B. Gavazov, V. D. Lekova, and G. I. Patronov, Acta Chim. Slov. 53 (2006) 506-511.

23. F. Genç, K. B. Gavazov, and M. Türkyilmaz, Cent. Eur. J. Chem. 8 (2010) 461-467.

24. K. B. Gavazov and P. V. Racheva, Asian Chem. Lett. 15 (2011) $77-84$.
25. V.S. Syrokomskii and Y.V. Klimenko, Vanadatometriya, Metallurgizdat, Moscow, 1950.

26. M. I. Bulatov and I. P. Kalinkin, Prakticheskoe rukovodstvo po fotokolorimetricheskim $i$ spektrofotometricheskim metodam analiza, Khimiya, Leningrad, 1986.

27. M. J. C. Taylor and J. F. Staden, Analyst 119 (1994) 1263-1276.

28. L. Marić and M. Široki, Anal. Chim. Acta 318 (1996) 345-355.

29. O. I. Karpova, V. V. Lukachina, and A. T. Pilipenko, Ukr. Khim. Zh. 39 (1973) 194-195.

30. R. M. Pogranichnaya, U. F. Goloborod'ko, and B. E. Reznic, Zh. Anal. Khim. 34 (1979) 917-921.

31. F. Genç, M. Türkyilmaz, and K. Gavazov, Sci. Res. Union Sci. Bulg. Plovdiv, Ser. B, 7 (2009) 85-90.

32. S. P. Mushran, O. Prakash, and J. R. Verma, Bull. Chem. Soc. Japan 45 (1972) 1709-1711.

33. M. F. Grigor'eva, R. Z. Zhosse, A. V. Kalyamin, and L. N. Moskvin, Zh. Anal. Khim. 50 (1995) 1101-1106.

34. F. I. Lobanov, G. K. Nurtaeva, and E. E. Ergozhin, Ekstraktsiya kompleksov ionov metallov s piridinovymi oksiazosoedineniyami, Nauka, Alma-Ata, 1983.

35. M. Langova, I. Klabenesova, K. Kasiura, and L. Sommer, Collection Czech. Chem. Commun. 41 (1976) 2386-2405.

36. S. Oszwaldowski and M. Jarosz, Chem. Anal. (Warsaw) 42 (1997) 739-756.

37. P. X. Baliza, S. L. C. Ferreira, and L. S. G. Teixeira, Talanta 79 (2009) 2-9.

38. A. T. Pilipenko and M. M. Tananajko, Raznoligandnye $i$ raznometall'nye kompleksy $i$ ikh primenenie $v$ analiticheskoi khimii, Khimiya, Moskow, 1983, p.74.

39. E.A. Morgen and L.M. Dimova, Zavod Lab. 50 (1984) 7-9.

40. E. Papp and J. Inczédy, Talanta 27 (1980) 49-51.

41. M. Široki and C. Djordjević, Anal. Chim. Acta 57 (1971) 301310.

42. L. Marić, M. Široki, Z. Štefanac, and M. J. Herak, Microchem. J. 24 (1979) 536-544. 